\title{
MACROECONOMIC INDICATORS AND FOREIGN DIRECT INVESTMENT IN INDONESIA
}

\author{
Fitriyah \\ Universitas Negeri Malang, Indonesia \\ Farida Rahmawati* \\ Universitas Negeri Malang, Indonesia \\ Bagus Shandy Narmaditya \\ Universitas Negeri Malang, Indonesia
}

\begin{abstract}
Indonesia has abundant diversity of resources to promote economic growth, and insufficient capital will lead to economic stagnation. This paper aims at examining the impact of macroeconomic indicators such as gross domestic product and inflation toward foreign direct investment in Indonesia as well as investigating the ease of doing business factors in explaining foreign direct investment. This research involved a time-series from 2014 to 2019, which was collected from several official websites of Statistics Indonesia (BPS), Central Bank of Indonesia (BI), the Investment Coordinating Board (BKPM), and World Bank. Furthermore, the data were analyzed undergoing multiple linear regression analyses with the Ordinary Least Square (OLS) model. The findings indicate that gross domestic product has a positive impact on foreign direct investment, while inflation has a negative effect. Also, the ease of doing business variables failed in explaining a significant influence between foreign direct investment in Indonesia.
\end{abstract}

JEL: B22, E22, O40.

Keywords: ease of doing business, inflation, foreign direct investment, gross domestic product.

\begin{abstract}
ABSTRAK
Indonesia memiliki keanekaragaman sumber daya yang melimpah untuk mendorong pertumbuhan ekonomi namun permasalahan permodalan menyebabkan kelambanan yang menyebabkan stagnasi ekonomi. Penelitian ini bertujuan untuk menguji pengaruh indikator makroekonomi seperti produk domestik bruto dan inflasi terhadap investasi asing langsung di Indonesia. Penelitian ini juga menyelidiki faktor-faktor kemudahan berbisnis dalam menjelaskan investasi asing langsung. Data penelitian ini adalah time-series 2014-2019, yang diperoleh dari beberapa situs resmi termasuk Badan Pusat Statistik (BPS), Bank Sentral Indonesia (BI), Badan Koordinasi Penanaman Modal (BKPM), dan Bank Dunia. Selanjutnya data tersebut dianalisis dengan menggunakan analisis regresi linier berganda dengan model Ordinary Least Square (OLS). Hasil penelitian menunjukkan bahwa produk domestik bruto berpengaruh positif terhadap investasi asing langsung, sedangkan inflasi berpengaruh negatif. Selain itu, variabel kemudahan berbisnis gagal menjelaskan pengaruh yang signifikan antara investasi asing langsung di Indonesia.
\end{abstract}

Kata Kunci: inflasi, investasi asing langsung, produk domestik bruto.

\section{INTRODUCTION}

Investment is fast becoming a vital instrument in a nation both in an advanced economy and in a developing country. Foreign and domestic investment in a country will determine the economic growth (Comes, Bunduchi, Vasile, \& Stefan, 2018; Yue, Yang, \& Hu, 2016). Foreign investment enhances additional capital that cannot be provided by domestic investment. Several studies believe that foreign investment impacts both in the short-term and long-term (Dinh, Vo, \&

\footnotetext{
*Email : farida.rahmawati.fe@um.ac.id

Received : 08-01-2021, Accepted : 20-04-2021, Published : 29-04-2021

P-ISSN : 2087-9954, E-ISSN : 2550-0066. DOI : http://dx.doi.org/10.26418/jebik.v10i1.44272
} 
Nguyen, 2019; Iamsiraroj, 2016). This is due to the fact that the critical role of foreign direct investment in transferring assets will be more efficient. Conversely, foreign investment can bring innovation to the host country to stimulate the economy through more valuable business activities.

Indonesia has abundant diversity of resources to promote economic growth. However, it does not be maximized due to several obstacles, such as insufficient capital. In the beginning, Indonesia was included in a country that declines foreign investment. The fundamental rationale is that it will undermine the country's sovereignty. Meanwhile, Indonesia needs to enhance its development and stimulate an investment climate useful for building and growing Indonesia's economy. The government enacted Law No. 1 of 1967 on foreign direct investment, then revised by Law No. 25 of 2007. By having an investment, a country will obtain a lot of capital that can be used to develop essential sectors. In fact, Indonesia is one of the countries becoming the investment destination in the world. Despite the fact that Indonesia is the fourth country investment destination, however, to the present, it has not been denied that competition to attract investors is still high with various facilities offered.

There are several considered factors affecting investment, such as economic, social, institutional, and political factors (Sharma, 2017; Haider, Gul, Afridi, \& Batool, 2017; Le, 2020). From the economic perspective, Bhattacharya \& Mukherjee (2016) mentioned that macroeconomic indicators such as GDP and inflation will determine investment decisions. In addition, Rehman, Khan, Pervaiz, \& Liaqat (2020) suggested that three main factors are able to produce an investment climate, namely macroeconomic, institutional, and infrastructure conditions. Furthermore, Regan \& Brazys (2018) mentioned that institutionalization includes the effectiveness of regulations, taxation, and the legal system. To measure the effectiveness of a provision that makes it easy to invest, the World Bank creates an Ease of Doing Business, which investigates regulations that increase business activities and rules that inhibit them.

The study on foreign direct investment and its determinant factors has heightened attention among policy research in the sphere. For instance, Asamoah, Adjasi, \& Alhassan (2016) revealed that macroeconomic uncertainty will affect the foreign direct investment in Sub-Sahara Africa. Meanwhile, Iamsiraroj (2016) noted that foreign direct investment has a causality with economic growth, and it is also determined by labor force and trade restrictions. Another example by Anitha (2012) showed a robust correlation between foreign direct investment and economic growth. Furthermore, Musyoka \& Ocharo (2018) emphasized that macroeconomic indicators, such as inflation and exchange rates, can explain foreign direct investment in Kenya, while in Nigeria, foreign direct investment can be affecting by investment climate and ease of doing business (Kofarbai \& Bambale, 2016).

Despite Indonesia as the Investment destination country, the study of determinant factors of foreign investment has been overlooked by scholars. The study in Indonesia mainly focuses on the impact of gross domestic product, foreign direct investment, and economic growth (Febriana \& Muqorobbin, 2014; Tambunan, Yusuf, \& Mayes, 2015). This paper's contribution is threefold. First, it contributes to the literature on determinant factors affecting foreign direct investment in Indonesia. The focused study in Indonesia is unique considering the abundant resources it has not maximized yet. Second, this study attempts to examine whether easy in doing business can influence foreign direct investment that was missing in the prior studies. Lastly, this study involves 
a time-series panel-data estimation that takes cross-sectional dependence into consideration in the model calculation.

The paper has been organized in the following way. The first section deals with the background of the study, followed by a literature review. The section provides the method and empirical model of econometric and is discussed in section 4. The last section involves the research's summary and suggestions.

\section{LITERATURE REVIEW}

Foreign investment is an activity to conduct business by a foreign investor in a country, either using entirely foreign capital or jointly with a domestic investor. Foreign investment consists of two types, including direct and indirect investment. Direct investment is defined as funds invested directly used to carry out business activities or conduct production equipment or facilities (Sarkodie \& Strezov, 2019). It helps developing countries to overcome the problem of underfunding foreign currency, accelerate economic development, bringing management staff, entrepreneurs, technical expertise, and market and marketing knowledge of the goods produced (Sabir, Rafique,\& Abbas, 2019; Self \& Connerley, 2019; Apostolov, 2017; Iwasaki \& Tokunaga, 2016).

Foreign investment can train indigenous people in obtaining expertise in the fields sought by foreign capital (Liu, Agbola, \& Dzator, 2016). Also, foreign companies can accelerate the transfer of new technology to developing countries (Salim, Razavi, \& Afshari, 2017). Second, indirect investment or portfolio investment, which mostly consists of control over shares that can be transferred (issued or guaranteed by the government of the capital importing country) on stocks or bonds by citizens and several other countries (Wang, 2019). However, ownership of the shares is not the same as the right to control the company. Therefore, shareholders have the right to dividends.

On the other hand, Gross Domestic Product (GDP) is considered a greater determinant of foreign direct investment and vice versa. GDP describes the total national income and total expenditure on the output of a country's goods and services (Rana, Alam, \& Gow, 2020). This implies that GDP is used to measure a country's total production of goods, services, and total income. The relationship between GDP and FDI is positive. The decrease in total output is proportional to the more significant investment (Fischer, 2016). Mathematically the relationship between GDP and investment can be seen in the following equation.

$$
K^{*}=g(r c, Y)
$$

Where $\mathrm{K} *$ is capital/investment, $\mathrm{rc}$ is the cost of capital (rent), and $\mathrm{Y}$ is the level of output/GDP. Thus, the equation shows that rising GDP can increase K or investment. This equation suggests that that GDP has a direct relationship with investment.

Another macroeconomic variable, inflation, is interpreted as an economic symptom that shows an increase in the level of prices, in general, that is continuous (Bernanke, Laubach, Mishkin, \& Posen, 2018)). The higher the inflation rate, the greater the uncertainty faced by creditors and debtors. This due to the fact that most people do not like uncertainty, so high inflation can interfere. Suppose it decides to implement a high inflation monetary policy. In that case, a country tends to accept high inflation, which will cause uncertainty for creditors and debtors by 
making them subject to large amounts of arbitrary wealth retribution (Taylor, 2019). Since high inflation causes uncertainty for debtors and creditors, it results in more significant business failure because it can affect production costs, impacting companies' profits, especially by creditors and debtors.

Ease of Doing Business (EoDB) can be calculated based on ten indicators, namely starting a business, dealing with construction permits, property registration, getting electricity, paying taxes, trading across borders, accessing credit, protecting minority investors, enforcing contracts, resolution of the resolving insolvency case (Jovanovic \& Jovanovic, 2018; Garcia \& Hinayon, 2018; Mahuni \& Bonga, 2017). The distance to the frontier of EoDB score ranges from 0-100 points, which shows the economic position of best regulatory practices. A lower score indicates worse business ease shown by 0 points, while the better the score in doing business is set at a score of 100 points. The percentage of scores on various indicators can be averaged together to get an aggregate score. In addition, the higher the EoDB rating, the better the regulations in force in a country.

\section{RESEARCH METHOD}

A quantitative study was applied to understand the factors affecting foreign direct investment in Indonesia. This study engaged three important variables, including gross domestic product, inflation, and ease of doing business with the time-series data from the first quarter of 2014 to the third quarter of 2019. The data were gathered from various sources, namely Statistics Indonesia (BPS), Central Bank of Indonesia (BI), the Investment Coordinating Board (BKPM), and the World Bank. The gross domestic product is determined at the basis of Indonesia's constant prices, while foreign direct investment is proxied by investment activity to do business carried out by foreign investors, whether using foreign capital fully or jointly with domestic investors. Additionally, Ease of Doing Business (EoDB) is illustrated by an index provided by the World bank. Furthermore, in analyzing and estimating time-series data, this study employed the E-views version 10. Data analyses have several stages, including multiple linear regression tests, the classic assumption test, and hypothesis testing. The use of Ordinary Least Square (OLS) aims to estimate a model that uses the smallest and simplest error squared method, wherein estimating using this estimator must meet several assumptions that must be obeyed in order to obtain an unbiased, consistent, efficient, and has an economic meaning that is in accordance with the theory. The following regression equation from this study:

$$
\hat{Y}=\beta_{0}+\beta_{1} X_{1 t}+\beta_{2} X_{2 t}+\beta_{3} X_{3 t}+e
$$

Note:

$$
\begin{array}{ll}
\hat{Y} & =\text { Foreign Direct Investment (FDI) } \\
X_{1} & =\text { Gross Domestic Products (GDP) } \\
X_{2} & =\text { Inflation (INF) } \\
X_{3} & =\text { Ease of Doing Business (EoDB) } \\
\beta_{0}, \beta_{1}, \beta_{2}, \beta_{3}, \beta_{4} & =\text { coefficient elasticity } \\
e & =\text { error term }
\end{array}
$$




\section{RESULTS AND DISCUSSION}

To estimate the impact of Gross Domestic Product (GDP), inflation, and ease of doing business toward Foreign Direct Investment (FDI) partially, it used multiple linear regression analysis with Ordinary Least Square (OLS) model. In more detail, the results of multiple linear regression are presented in Table 1.

Table 1. The result of regression analysis

\begin{tabular}{lcccc}
\hline \multicolumn{1}{c}{ Variable } & Coefficient & Std. Error & t-Statistic & Prob. \\
\hline C & 1.874429 & 2.695665 & 0.695349 & 0.4953 \\
LnGDP & 0.655917 & 0.188855 & 3.473115 & 0.0025 \\
INF & -0.039894 & 0.014284 & -2.793027 & 0.0116 \\
EoDB & 0.007526 & 0.028770 & 0.261606 & 0.7964 \\
R-Squared & 0.783791 & & & \\
Adjusted R-Squared & 0.749652 & & & \\
F-Statistic & 22.95927 & & & \\
Prob (F-statistic) & 0.000002 & & & \\
\hline
\end{tabular}

$$
\operatorname{LnFDI}=1.874429+0.655917 \operatorname{LnGDP}-0.039894 I N F+0.007526 E o D B
$$

A constant score of 1.874429 indicates that if the Gross Domestic Product (GDP), inflation, and Ease of Doing Business (EoDB) are constant, the amount of foreign direct investment (FDI) increases by 1.87 percent. Then, the coefficient of GDP of 0.655917 indicates that the GDP has a positive and significant effect on FDI. This implies that an increase in GDP by 1 percent will FDI by 0.66 percent. Furthermore, the coefficient of inflation of-0.039894 indicates that inflation has a negative and significant effect on FDI. This result suggests that an increase in inflation of 1 percent will reduce FDI by 0.04 percent. Lastly, the EoDB coefficient of 0.007526 indicates that the EoDB has a positive relationship but has no significant effect on FDI.

Based on the estimation results in Table 1, it shows that the GDP has a significant effect on FDI in Indonesia in the first quarter of 2014 - the third quarter of 2018, with a coefficient value of 0.655917, which means that when the Gross Domestic Product (GDP) has increased by 1 percent, the FDI will increase by 0.66 percent. This study's results show a positive relationship between GDP and FDI in Indonesia in the first quarter of 2014-quarter III of 2019. The increase in Gross Domestic Product (GDP) reflects the increasing Indonesian income and has an impact on the increased demand for goods and services. Therefore, people's purchasing power will increase. When purchasing power increases, the demand for goods and services also increases. And this can benefit the company due to increased demand for these goods. Thus, investments will experience profits, so they are interested in investing.

This finding is in line with the prior studies by Febriana \& Muqorobbin (2014), which mentioned that in the short and long term, GDP has a significant positive effect on FDI. This implies that GDP plays an important part in influencing FDI. Indeed, this finding agrees with Tambunan et al. (2015), who remarked that a positive and significant effect on the realization of FDI in Indonesia in 1998-2013. The GDP is the same as the national income of a country, with a high level of income that will affect people's income, high community income will increase the demand for goods and services. Therefore, the company's profits will increase, and this can encourage investment. Malisa \& Fakhruddin (2017) remarked that a positive impact of GDP and 
FDI being a strong signal for investors to make investments, but this investment is in the form of investment with the initial goal of rapid returns due to high economic growth.

In addition, this study found a negative impact between inflation and FDI in Indonesia. In other words, the decreasing inflation will raise FDI in Indonesia and vice versa. Inflation rates fluctuation can affect the ups and downs of prices of a product in a country. The higher inflation rates will impact the inclining production costs and less profitable for a company. The finding of this study is in accordance with the theory of Perez (2019), which mentioned that the higher rate of inflation will affect the greater the uncertainty faced by creditors and debtors. Because most people do not like uncertainty so that high inflation can be disturbing. This indicates that inflation has a negative relationship to investment because the high inflation causes uncertainty for debtors and creditors, which results in greater business failure. After all, it can affect production costs, which have an impact on profits obtained by companies, especially by creditors and debtors.

The results of this study are in line with the antecedent study by Sarungu \& Maharsi (2013) and Septifany (2015), which remarked that inflation has a negative and significant effect on the amount of investment in the long run. It is hoped that the policymakers can maintain a stable level of inflation so investors can invest their capital in Indonesia. Indeed, this study supports a prior study by Anwar (2016) that inflation has a significant negative effect on FDI in the Southeast Asian Region. This means that when inflation rises, FDI falls, and this is in accordance with inflation theory, which is cost-push inflation that occurs due to an increase in production costs that results in a decrease in aggregate supply due to a rise in production costs that has an impact on prices and purchasing power which decreases, causing the level of risk of business failure to be even higher, which in the end the investment becomes less attractive.

The last purpose of the study aims to determine the impact of Ease of Doing Business (EoDB) on FDI. The results of this study indicate a positive relationship but not significant between EoDB and FDI in Indonesia. This means that if the ease of doing good business reflected by efficient, simple, and easy regulations will make investors willing to invest in Indonesia so that foreign investment will increase, and vice versa. This study confirms previous work by Morris \& Aziz (2011), which showed that ease of doing business has a positive relationship with FDI in 2000-2001 in Sub-Saharan Africa and Asian countries and regions of Sub-Saharan African countries in 2001-2005. However, in Asian countries from 2001-2005, ease of doing business was not significantly related to FDI. The fundamental argument is that two factors are related to FDI, namely cross-border trade and contract enforcement. Also, it seems that FDI is not merely influenced by the ease of doing business in making investment decisions in both African and Asian countries, for example, based on the broad market offered by Asian countries. Similarly, Jovanovic \& Jovanovic (2018) show uncertainty about the impact of ease of doing business because most indicators are insignificant or lack strength.

When viewed the distance to the EoDB score's frontier, Indonesia's EoDB rank from 2014-2019 increases every year from 60.7 points to 68.2 points. However, the EoDB rating decreased in 2019, from 72 in 2018 to 73 . This decline is caused by other countries that make reforms faster in their respective fields. These countries such as China, India, and Kenya. Where the change or increase in EoDB scores of the three countries is quite significant from 2018 to 2019, each was increasing by 8.64 points, 6.63 points, and 5.25 points. Meanwhile, Indonesia only increased by 1.3 points from 66.9 points to 68.2 points. For example, four EoDB indicators caused 
Indonesia's ranking to drop in 2019. The two signs experienced a slight increase. These indicators are licensing related to building construction permits and cross-border trading, each of which increased by 0.49 points from 66.08 points to 66.57 points, and 0.68 points from 66.59 points to 67.27 points. Moreover, there are also indicators that did not experience an increase in the distance to the frontier core in 2019, or the range to frontier score value is fixed when compared to 2018. These indicators are the protection of minority investors and the enforcement of contracts. Thus, the effect of the insignificant EoDB score on FDI is caused by the insignificant changes in the EoDB score, which means that improvements in regulations in Indonesia both in terms of accessibility, efficiency, and simplicity are still felt to be lacking where there are still a few indicators whose scoring increases are not significant, and there are also some indicators that do not experience improvement indicated by scores that do not experience growth but are fixed.

\section{CONCLUSION AND RECOMMENDATION}

This study is intended to examine the impact of macroeconomic variables and foreign direct investment in Indonesia. Based on the previous analysis and discussion, it can be concluded that gross domestic product has a positive impact on foreign direct investment. In contrast, inflation has a negative correlation toward foreign direct investment. Also, another variable, ease of doing business, cannot significantly influence foreign direct investment in Indonesia. These findings suggest that the government is expected to make policies to increase gross domestic product and maintain inflation stability. Furthermore, it also needs to improve regulations for ease of doing business that make investors are willing to invest their capital. Investors need to consider factors that can influence foreign investment, such as gross domestic product, inflation, and ease of doing business that can help investors make investment decisions so that they can be profitable. Another possibility disconcerts, including transport and infrastructure, political situation, and wage rates, also have the potential to promote foreign direct investment in Indonesia. This study leaves the investigation of these potential variables to forthcoming research.

\section{REFERENCES}

Anitha, R. (2012). Foreign Direct Investment and Economic Growth in India. International Journal of Marketing, Financial Services \& Management Research, 1(8), 108-125.

Anwar, C. J. (2016). Faktor-Faktor Yang Mempengaruhi Foreign Direct Investment (FDI) di Kawasan Asia Tenggara. Media Trend, 11(2), 175-194.

Apostolov, M. (2017). The Impact of FDI on the Performance and Entrepreneurship of Domestic Firms. Journal of International Entrepreneurship, 15(4), 390-415.

Asamoah, M. E., Adjasi, C. K., \& Alhassan, A. L. (2016). Macroeconomic Uncertainty, Foreign Direct Investment and Institutional Quality: Evidence from Sub-Saharan Africa. Economic Systems, 40(4), 612-621.

Bernanke, B. S., Laubach, T., Mishkin, F. S., \& Posen, A. S. (2018). Inflation Targeting: Lessons from the International Experience. Princeton University Press.

Bhattacharya, B., \& Mukherjee, J. (2016). Foreign Direct Investment and Macroeconomic Indicators in India: A Causality Analysis. In International Trade and International Finance, Springer, New Delhi, 373-384. 
Comes, C. A., Bunduchi, E., Vasile, V., \& Stefan, D. (2018). The Impact of Foreign Direct Investments and Remittances on Economic Growth: A Case Study in Central and Eastern Europe. Sustainability, 10(1), 1-16.

Dinh, T. T. H., Vo, D. H., \& Nguyen, T. C. (2019). Foreign Direct Investment and Economic Growth in the Short Run and Long Run: Empirical Evidence from Developing Countries. Journal of Risk and Financial Management, 12(4), 176-188.

Febriana, A., \& Muqorobbin, M. (2014). Investasi Asing Langsung di Indonesia dan Faktor-Faktor yang Mempengaruhinya. Jurnal Ekonomi dan Studi Pembangunan, 15(2), 109-117.

Fischer, S. (2016). Reflections on Macroeconomics Then and Now. Business Economics, 51(3), 133-141.

Garcia, C. M., \& Hinayon, D. E. (2018). Components of Ease of Doing Business Inferred from Macroeconomic Performance Indicators. Journal of Educational and Human Resource Development, 6, 161-171.

Haider, M., Gul, S., Afridi, S. A., \& Batool, S. (2017). Factors Affecting Foreign Direct Investment in Pakistan. NUML International Journal of Business \& Management, 12(2), 136-149.

Iamsiraroj, S. (2016). The Foreign Direct Investment-Economic Growth Nexus. International Review of Economics \& Finance, 42, 116-133.

Iwasaki, I., \& Tokunaga, M. (2016). Technology Transfer and Spillovers from FDI in Transition Economies: A meta-analysis. Journal of Comparative Economics, 44(4), 1086-1114.

Jovanovic, B., \& Jovanovic, B. (2018). Ease of Doing Business and FDI in the Ex-Socialist Countries. International Economics and Economic Policy, 15(3), 587-627.

Kofarbai, H. Z., \& Bambale, A. J. A. (2016). Investment Climate and Foreign Direct Investment in Nigeria: The Mediating Role of Ease of Doing Business. Journal of Energy and Economic Development, 2(2), 40-52.

Le, B. (2020). New Evidence for the Determinants of Foreign Investment in an Asian Market. Afro-Asian Journal of Finance and Accounting, 10(2), 151-167.

Liu, W. S., Agbola, F. W., \& Dzator, J. A. (2016). The Impact of FDI Spillover Effects on Total Factor Productivity in the Chinese Electronic Industry: A Panel Data Analysis. Journal of the Asia Pacific Economy, 21(2), 217-234.

Mahuni, K., \& Bonga, W. G. (2017). Nexus Between Doing Business Indicators and Foreign Direct Investment for Zimbabwe: A Time Series Analysis. Journal of Economics and Finance, 2(2), 1-8.

Malisa, M., \& Fakhruddin, F. (2017). Analisis Investasi Langsung di Indonesia. Jurnal Ilmiah Mahasiswa Ekonomi Pembangunan, 2(1), 116-124.

Morris, R., \& Aziz, A. (2011). Ease of Doing Business and FDI Inflow to Sub-Saharan African and Asian Coutries. Cross Cultural Management, 18(4), 400-441.

Musyoka, N., \& Ocharo, K. N. (2018). Real Interest Rate, Inflation, Exchange Rate, Competitiveness and Foreign Direct Investment in Kenya. American Journal of Economics, 3(1), 1-18.

Perez, S. A. (2019). A Europe of Creditor and Debtor States: Explaining the North/South Divide in the Eurozone. West European Politics, 42(5), 989-1014.

Rana, R. H., Alam, K., \& Gow, J. (2020). Health Expenditure and Gross Domestic Product: Causality Analysis by Income Level. International Journal of Health Economics and Management, 20(1), 55-77. 
Regan, A., \& Brazys, S. (2018). Celtic Phoenix or Leprechaun Economics? The Politics of an FDILed Growth Model in Europe. New Political Economy, 23(2), 223-238.

Rehman, F. U., Khan, M. A., Khan, M. A., Pervaiz, K., \& Liaqat, I. (2020). The Causal, Linear and Nonlinear Nexus Between Sectoral FDI and Infrastructure in Pakistan: Using A New Global Infrastructure Index. Research in International Business and Finance, 52, 1-31.

Sabir, S., Rafique, A., \& Abbas, K. (2019). Institutions and FDI: Evidence from Developed and Developing Countries. Financial Innovation, 5(1), 8-28.

Salim, A., Razavi, M. R., \& Afshari-Mofrad, M. (2017). Foreign Direct Investment and Technology Spillover in Iran: The Role of Technological Capabilities of Subsidiaries. Technological Forecasting and Social Change, 122, 207-214.

Sarkodie, S. A., \& Strezov, V. (2019). Effect of Foreign Direct Investments, Economic Development and Energy Consumption on Greenhouse Gas Emissions in Developing Countries. Science of the Total Environment, 646, 862-871.

Sarungu, J. J., \& Maharsi, E. K. (2013). Analisis Faktor yang Mempengaruhi Investasi di Indonesia Tahun 1990-2010: Metode ECM. Jurnal Ekonomi Kuantitatif Terapan, 6(2), 112-117.

Self, S., \& Connerley, M. L. (2019). Job Creation and FDI: The Role of Economic, Social, and Political Climate in Developing Countries. Journal of Economic Insight, 45(2), 1-18.

Septifany, A. T. (2015). Analisis Pengaruh Inflasi, Tingkat Suku Bunga, Nilai Tukar Rupiah dan Cadangan Devisa terhadap Penanaman Modal Asing di Indonesia. Jurnal Administrasi Bisnis (JAB), 25(2), 1-7.

Sharma, S. (2017). Factors Affecting Foreign Direct Investment. International Journal of Management, IT and Engineering, 7(2), 1-8.

Tambunan, R. S., Yusuf, Y., \& Mayes, A. (2015). Pengaruh Kurs, Inflasi, Libor dan PDB terhadap Foreign Direct Investment (FDI) di Indonesia. Jurnal Ekonomi, 23(1), 59-84.

Taylor, J. B. (2019). Inflation Targeting in High Inflation Emerging Economies: Lessons About Rules and Instruments. Journal of Applied Economics, 22(1), 103-116.

Wang, L. (2019). Stock Market Valuation, Foreign Investment, and Cross-Country Arbitrage. Global Finance Journal, 40, 74-84.

Yue, S., Yang, Y., \& Hu, Y. (2016). Does Foreign Direct Investment Affect Green Growth? Evidence from China's Experience. Sustainability, 8(2), 44-50. 